\title{
Yield and yield attributes of rapeseed cultivars as influence by sulfur level under Swat valley conditions
}

\author{
Imran $^{1 *}$, Asad Ali Khan ${ }^{1}$, Inamullah ${ }^{1}$, Hayat Zada ${ }^{2}$, Fayaz Ahmad ${ }^{1}$, Syed \\ Tanveer Shah ${ }^{3}$, Amjad Usman ${ }^{4}$ and Irfanullah ${ }^{3}$ \\ 1. Department of Agronomy, The University of Agriculture, Peshawar, Pakistan. \\ 2. Department of Plant Protection, The University of Agriculture, Peshawar, Pakistan. \\ 3. Department of Horticulture, The University of Agriculture, Peshawar, Pakistan. \\ 4. Department of Entomology, The University of Agriculture, Peshawar, Pakistan \\ *Corresponding author's email: imranagrarian@aup.edu.pk

\section{Citation} \\ Imran, Asad Ali Khan, Inamullah, Hayat Zada, Fayaz Ahmad, Syed Tanveer Shah, Amjad Usman and Irfanullah. \\ Yield and yield attributes of rapeseed cultivars as influence by sulfur level under Swat valley conditions. Pure and \\ Applied Biology. Vol. 4, Issue 3, 2015, pp 296-301. http://dx.doi.org/10.19045/bspab.2015.43003
}

Received: 21/04/2015

Revised: 03/07/2015

Accepted: 10/07/2015

\section{Abstract}

The performance of rapeseed cultivars (Brassica napus L.) was evaluated using various sulfur levels at the Agriculture Research Institute (N) Mingora swat, Pakistan during Rabi season 201213. The experiment was laid out in randomized complete block design with four replications. Four level of sulfur $\left(0,15,30\right.$, and $\left.45 \mathrm{~kg} \mathrm{ha}^{-1}\right)$ and four cultivars of rapeseed (Oscar, Bulbul-98, Dunkled, and Abasin-95) were used. Rapeseed cultivars were significant for all the parameters. The cultivar Oscar had the maximum capsules plant $^{-1}$ (360), seed capsule ${ }^{-1}$ (24), 1000 seed weight (3.38 g), seed yield $\left(2340 \mathrm{~kg} \mathrm{ha}^{-1}\right)$, oil yield (1132 $\left.\mathrm{kg} \mathrm{ha}^{-1}\right)$ and harvest index (17\%) as compared with other rapeseed cultivars. Sulfur application was significant for all parameters. Plots treated with $45 \mathrm{~kg} \mathrm{~S}^{-1}$ produced maximum capsules plant ${ }^{-1}$ (407), seed capsule ${ }^{-1}$ (26), 1000 grain weight $(3.61 \mathrm{~g})$, grain yield $\left(2701 \mathrm{~kg} \mathrm{ha}^{-1}\right)$, oil yield $\left(1291 \mathrm{~kg} \mathrm{ha}^{-1}\right)$ and harvest index $(18 \%)$ as compared with control plots. It was concluded from this study that sowing of cultivar Oscar with $45 \mathrm{~kg} \mathrm{~S}^{-1}$ seems to the best choice for rapeseed producer in the agro-ecological condition of Swat valley.

Key words: Rapeseed (Brassica napus L.); sulfur; oil yield; seed yield; yield components.

\section{Introduction}

Rapeseed (Brassica napus L.) is one of the important members of the plant family Cruciferae. There are about 160 species within the genus Brassica [1, 2]. The crop has been rich source of the edible oil but the existence of erucic acid and glucosinolate (the sulfur compounds) in the tissues make it toxic and noxious for both human and animal's health, and has a bitter taste. Due to the existence of these chemicals, it has not earned a prominent position as an oil seed crop [3, 4]. Safety restrictions for these compounds have been described as less than $2 \%$ erucic acid in oil, and less than $30 \mathrm{u}$ mol $\mathrm{g}^{-1}$ of glucosinolates in oil free meal $[5,6]$. To reduce the levels of erucic acid and glucosinolates to satisfactory level plant breeders in Canada converted rapeseed species to canola and made it the world's 
most essential vegetable oil after soybean and palm [7]. Rapeseed is an important edible oilseed crop however its yield very low (Average $<812 \mathrm{~kg} \mathrm{ha}^{-1}$ ) in Pakistan [8]. While the average production in Canada is $3200 \mathrm{~kg} \mathrm{ha}^{-1}$ and Australia $2000 \mathrm{Kg} \mathrm{ha}^{-1}$ [9]. Fertilizers application has always played the key role in boosting crop production and sulfur is the fourth major fundamental plant nutrient after nitrogen $(\mathrm{N})$, phosphorus $(\mathrm{P})$ and potassium $(\mathrm{K})$. It is needed for manufacturing of the amino acids like cystine and methionine, a constituent of vitamin $A$ and involved in reaction of certain enzyme systems within the plants [10]. Under S scarcity and poor conditions, the efficiency of applied NPK fertilizers may be compromised and crop productivity may not be sustainable [3]. The total consumption and utilization of all the major nutrients (NPK) in Pakistan was about 3694 millions tons during 2004-05 [11]. Sulfur (S) is not considered as a plant nutrient in fertilization practices in Pakistan and very little is known about $S$ status of soils in the country [3]. Application of different sources of $\mathrm{S}$ fertilizers $\left(10\right.$ to $\left.45 \mathrm{~kg} \mathrm{ha}^{-1}\right)$ significantly advanced the seed yield of rapeseed and mustard crops ranging from 5.2 to $76.7 \%$ as compared to control in soil of Potwar, Pakistan [5]. Soleymani et al. [12] concluded from field experiment that $S$ deficiency is limiting factor for canola seed and oil production. He used three levels of sulfur (0, 125 and $\left.145 \mathrm{~kg} \mathrm{ha}^{-1}\right)$ and three varieties (RGS003, Hyola401 and Hyola420) sulfur had significant effect on oil percentage $(\%)$, grain yield, oil yield and harvest index. Sulfur is one of the most important major secondary elements required for the growth and development of rapeseed which deserve particular attention. Keeping in view the limitations under rainfed condition this research was conducted under irrigated intensive agricultural conditions. To find out the most suitable rapeseed cultivars and sulfur levels for higher yield in the agro-climatic condition of swat valley.

\section{Materials and Methods}

The experiment was conducted at the Agriculture research institute (N) Mingora swat, Pakistan during Rabi season 2012-13. The experiment was laid out in randomized complete block design with four replications. Four levels of sulfur $(0,15,30$, and $45 \mathrm{~kg} \mathrm{ha} \mathrm{ha}^{-1}$ ) and four cultivars of rapeseed (Oscar, Bulbul-98, Dunkled, and Abasin-95) were used with a plot size of $5 \mathrm{~m}$ x $2.7 \mathrm{~m}$ with 6 rows and $45 \mathrm{~cm}$ spacing. Phosphorous was applied at $60 \mathrm{~kg} \mathrm{ha}^{-1}$ in the form of SSP at the time of sowing. Nitrogen in the form of urea was applied at $80 \mathrm{~kg} \mathrm{ha}^{-1}$, and a half dose was applied at sowing time and the remaining half was at flowering stage. Sulfur was applied in the form of elemental sulfur. Seeds of these cultivars (Oscar, Bulbul-98, Dunkled, and Abasin-95) were sowed in the $3^{\text {rd }}$ week of October 2012. Agronomic practices were carried out uniformly for all the experimental units throughout the growing season.

Number of capsule plant $^{-1}$ was counted for ten plants selected randomly in each subplot. Seed capsule ${ }^{-1}$ was recorded by counting seed in ten capsules selected randomly in each sub plot. After threshing data form thousand grains weight $(\mathrm{g})$ were recorded for three seed lots and weighed with the help of electronic balance. Four central rows in each sub plots were harvested, sun dried and threshed. Seed weight was taken with the help of electronic balance and then converted into $\mathrm{kg} \mathrm{ha} \mathrm{ha}^{-1}$ by the following formula.

Grain yield $\left(\mathrm{kg} \mathrm{ha}^{-1}\right)=$ Grains weight in four rows $(\mathrm{kg}) /$ No of Rows x Row length x R-R x 10,000 $\mathrm{m}^{2}$

Oil yield can be calculated by the following formula.

Oil yield $\left(\mathrm{kg} \mathrm{ha}^{-1}\right)=$ Oil content \% x seed yield $(\mathrm{kg}$ $\left.\mathrm{ha}^{-1}\right) / 100$ 
Harvest index was calculated by using the following formula.

Harvest Index $(\%)=$ Grain yield $\left(\mathrm{kg} \mathrm{ha}^{-1}\right) /$ Biological yield $\left(\mathrm{kg} \mathrm{ha}^{-1}\right) \times 100$

All data collected were subjected to analysis of variance (ANOVA) with the help of statistical software, Statistix 8.0 USA (2005). Upon significant F-Test, least significance difference (LSD) test was used for mean comparison to identify the significant components of the treatment means [13].

\section{Results and Discussion \\ Number of capsules plant ${ }^{-1}$}

Data presented in Table 1 indicated that the levels of sulfur and cultivars had significant effect on number of capsules plant ${ }^{-1}$ while the interaction between $\mathrm{S} \times \mathrm{C}$ had no significant effect on capsules plant ${ }^{-1}$. Mean values of data indicated that plots treated with $45 \mathrm{~kg} \mathrm{~S} \mathrm{ha}^{-1}$ produced maximum (407) number of capsules plant $^{-1}$ while minimum (262) number of capsules plant ${ }^{-1}$ was recorded in control plots. These results agree with $[5,6]$ who reported that $S$ induced significant increase in capsules plant ${ }^{-1}$. In control plots number of pods varied from 290 to 300 pods plant $^{-1}$ and increased gradually from 400 to 430 pods plant $^{-1}$ when sulfur applied up to $80 \mathrm{~kg} \mathrm{ha}^{-1}$. Rapeseed cultivars had also significant effect on number of capsules plant ${ }^{-1}$. Sowing of cultivar Oscar produces more (368) number of capsules plant $^{-1}$ while lowest (345) number of capsules plant ${ }^{-1}$ produce by Dunkled. Similar results were reported by [6] who studied that improved canola cultivars produced more number of pods plant $^{-1}$ as compared to local cultivars. The difference among the cultivars might be due to genetic makeup and nutrients absorption.

\section{Number of seeds capsule ${ }^{-1}$}

Statistical analysis of the data indicated that sulfur levels and cultivars had significant effect on number of seeds capsule ${ }^{-1}$. Seeds capsule $^{-1}$ were increased with increase in sulfur levels. Mean value of the sulfur level indicated that plot treated with $45 \mathrm{~kg} \mathrm{ha}^{-1}$ produced maximum (26) number of seeds capsule $^{-1}$ while the lowest (18) seeds capsule $^{-1}$ was recorded in control plots. These results agree with those of [14] that significant differences in number of seeds capsule $^{-1}$ were recorded among $\mathrm{S}$ levels. Less (20) number of seeds capsule ${ }^{-1}$ were noted in control plots when sulfur levels were enhanced from 0 to $45 \mathrm{~kg} \mathrm{ha}^{-1}$, number of seeds increased from 20 to 30 capsule $^{-1}$. Sowing of cultivars Oscar produced maximum (25) number of seeds capsule ${ }^{-1}$ while minimum (20) seeds capsule ${ }^{-1}$ produced by Abasin-95. Bulbul-98 and Dunkled were statistically on par. These results agree with those of [5] who reported that the difference in seeds capsule ${ }^{-1}$ among the cultivars might be due to genetically determined differences in uptake of nutrient especially sulfur. Interaction between $\mathrm{S}$ x $\mathrm{C}$ indicated by table 2 that all rapeseed cultivars produced maximum number of seeds capsule ${ }^{-1}$ with increasing sulfur level up to $30 \mathrm{~kg} \mathrm{ha}^{-1}$. Sharp increases in seeds capsule ${ }^{-1}$ occurred in cultivar Oscar at $45 \mathrm{~kg} \mathrm{~S} \mathrm{ha}^{-1}$.

\section{Thousand seed weight (g)}

Mean values of rapeseed cultivars indicated that the sown cultivar Oscar produced heavier $(3.38 \mathrm{~g})$ seed weight while the minimum (3.08 g) seed weight was recorded by Abasin-95, these results were similar to those reported by [9] that differences among the 1000 grains weight in these cultivars might be due to hereditary superiority, growth rate, crop potential of yield, higher nutrients translocation, assimilation and dry matter partitioning. Plots treated with $45 \mathrm{~kg} \mathrm{~S}^{-1}$ produced heavier $(3.61 \mathrm{~g})$ seed weight, followed by $30 \mathrm{~kg} \mathrm{~S} \mathrm{ha}^{-1}$ produced $(3.38 \mathrm{~g}$ ) seed weight while minimum seed weight $(2.75$ g) was recoded in control plots. 
Table 1. Number of capsules plant ${ }^{-1}$, number of seeds capsule ${ }^{-1}$, thousand grains weight (g), grain yield $\left(\mathrm{kg} \mathrm{ha}^{-1}\right)$, oil yield $\left(\mathrm{kg} \mathrm{ha}^{-1}\right)$ and harvest index \% of Rapeseed cultivars as affected by sulfur levels

\begin{tabular}{|c|c|c|c|c|c|c|}
\hline Treatment & $\begin{array}{l}\text { No. of } \\
\text { capsules } \\
\text { plant }^{-1}\end{array}$ & $\begin{array}{l}\text { No. of } \\
\text { seeds } \\
\text { capsule }\end{array}$ & $\begin{array}{l}1000 \text { seed } \\
\text { weight }(\mathrm{g})\end{array}$ & $\begin{array}{l}\text { Seed yield (kg } \\
\left.\mathrm{ha}^{-1}\right)\end{array}$ & $\begin{array}{l}\text { Oil yield (kg } \\
\left.\mathrm{ha}^{-1}\right)\end{array}$ & H.I \% \\
\hline \multicolumn{7}{|c|}{ Sulfur $\left(\mathrm{kg} \mathrm{ha}^{-1}\right)$} \\
\hline 0 & $262 \mathrm{~d}$ & $18 \mathrm{~d}$ & $2.75 \mathrm{~d}$ & $1356 \mathrm{~d}$ & $642 \mathrm{~d}$ & $15 \mathrm{c}$ \\
\hline 15 & $337 \mathrm{c}$ & $21 \mathrm{c}$ & $3.03 \mathrm{c}$ & $1943 \mathrm{c}$ & $919 \mathrm{c}$ & $16 \mathrm{~b}$ \\
\hline 30 & $372 \mathrm{~b}$ & $23 \mathrm{~b}$ & $3.38 \mathrm{~b}$ & $2275 \mathrm{~b}$ & $1102 \mathrm{~b}$ & $16 \mathrm{~b}$ \\
\hline 45 & $407 \mathrm{a}$ & $26 \mathrm{a}$ & $3.61 \mathrm{a}$ & $2701 \mathrm{a}$ & $1291 \mathrm{a}$ & $18 \mathrm{a}$ \\
\hline LSD (0.05) & 10.34 & 1.05 & 0.20 & 74.71 & 39.97 & 0.76 \\
\hline \multicolumn{7}{|l|}{ Cultivars } \\
\hline Oscar & $360 \mathrm{a}$ & $24 \mathrm{a}$ & $3.38 \mathrm{a}$ & $2340 \mathrm{a}$ & $1132 \mathrm{a}$ & $17 \mathrm{a}$ \\
\hline Bulbul-98 & $338 \mathrm{bc}$ & $22 \mathrm{~b}$ & $3.17 \mathrm{~b}$ & $2058 \mathrm{~b}$ & $985 \mathrm{~b}$ & $17 \mathrm{a}$ \\
\hline Dunkled & $335 \mathrm{c}$ & $22 \mathrm{~b}$ & $3.11 \mathrm{~b}$ & $1929 \mathrm{c}$ & $913 \mathrm{c}$ & $16 \mathrm{~b}$ \\
\hline Abasin-95 & $346 \mathrm{~b}$ & $20 \mathrm{c}$ & $3.08 \mathrm{~b}$ & $1949 \mathrm{c}$ & $923 \mathrm{c}$ & $15 \mathrm{c}$ \\
\hline LSD (0.05) & 10.34 & 1.05 & 0.20 & 74.71 & 39.97 & 0.76 \\
\hline \multicolumn{7}{|l|}{ Interaction } \\
\hline $\mathrm{S} \times \mathrm{C}$ & ns & $*$ & $*$ & $*$ & * & ns \\
\hline
\end{tabular}

Means in the same category followed by different letters are significantly different at $\mathrm{P} \leq 0.05$ levels. ns $=$ non-significant

Table 2. Interaction effects of sulfur levels and rapeseed cultivars on number of seeds capsule ${ }^{-1}$, thousand seed weight $(\mathrm{g})$, seed yield $\left(\mathrm{kg} \mathrm{ha}^{-1}\right)$ and oil yield $\left(\mathrm{kg} \mathrm{ha}^{-1}\right)$

\begin{tabular}{|c|c|c|c|c|}
\hline $\begin{array}{l}\text { Cultivars } x \\
\text { Sulfur }\left(\mathrm{kg} \mathrm{ha}^{-1}\right)\end{array}$ & $\begin{array}{l}\text { No. of seeds } \\
\text { capsule }^{-1}\end{array}$ & $\begin{array}{l}1000 \text { seed weight } \\
(\mathrm{g})\end{array}$ & $\begin{array}{l}\text { Seed yield (kg ha- } \\
\left.{ }^{1}\right)\end{array}$ & Oil yield $\left(\mathrm{kg} \mathrm{ha}^{-1}\right)$ \\
\hline Oscar x 0 & 20de & $2.86 \mathrm{i}$ & $1500 \mathrm{j}$ & $716 \mathrm{i}$ \\
\hline Oscar x 15 & $23 c$ & $3.30 \mathrm{f}$ & $2203 \mathrm{ef}$ & $1057 \mathrm{de}$ \\
\hline Oscar x 30 & $25 \mathrm{~b}$ & $3.54 \mathrm{c}$ & $2537 b c$ & $1237 \mathrm{~b}$ \\
\hline Oscar x 45 & $28 \mathrm{a}$ & $3.88 \mathrm{a}$ & $3120 \mathrm{a}$ & $1518 \mathrm{a}$ \\
\hline Bulbul-98 x 0 & $19 \mathrm{ef}$ & $2.74 \mathrm{j}$ & $1375 \mathrm{jk}$ & $641 \mathrm{ij}$ \\
\hline Bulbul-98 x 15 & $21 d$ & $2.99 \mathrm{~g}$ & $1973 \mathrm{gh}$ & $929 \mathrm{fg}$ \\
\hline Bulbul-98 x 30 & $23 c$ & $3.34 \mathrm{e}$ & $2273 \mathrm{dc}$ & $1120 \mathrm{~cd}$ \\
\hline Bulbul-98 x 45 & $25 b$ & $3.60 \mathrm{~b}$ & $2611 b$ & $1252 b$ \\
\hline Dunkled x 0 & $18 \mathrm{fg}$ & $2.71 \mathrm{jk}$ & $1300 \mathrm{k}$ & $631 \mathrm{j}$ \\
\hline Dunkled x 15 & $21 \mathrm{~d}$ & $2.92 \mathrm{~h}$ & 1815hi & $849 \mathrm{gh}$ \\
\hline Dunkled x 30 & $23 c$ & $3.33 \mathrm{ef}$ & $2197 \mathrm{ef}$ & $988 \mathrm{ef}$ \\
\hline Dunkled x 45 & $25 b$ & $3.51 \mathrm{c}$ & $2541 b c$ & $1183 \mathrm{dc}$ \\
\hline Abasin-95 x 0 & $17 \mathrm{~g}$ & $2.69 \mathrm{k}$ & $1250 \mathrm{k}$ & $580 \mathrm{j}$ \\
\hline Abasin-95 x 15 & $20 \mathrm{de}$ & $2.88 \mathrm{i}$ & $1783 \mathrm{i}$ & $840 \mathrm{~h}$ \\
\hline Abasin-95 x 30 & $23 c$ & $3.30 \mathrm{f}$ & $2093 \mathrm{fg}$ & 1061de \\
\hline Abasin-95 x 45 & $25 \mathrm{~b}$ & $3.42 \mathrm{~d}$ & $2431 \mathrm{~cd}$ & $1210 \mathrm{~b}$ \\
\hline LSD (0.05) & 1.31 & 0.034 & 158.5 & 80.04 \\
\hline
\end{tabular}


These results agree with those of [14] who reported that increasing sulfur application significantly increased the seed weight. Interaction between $\mathrm{S} x \mathrm{C}$ indicated by table 2 that all rapeseed cultivars increased by 1000 grain weight up to $30 \mathrm{~kg} \mathrm{~S} \mathrm{ha-1}$. However the maximum increase was recorded for 1000 grain weight when the cultivar Oscar treated with $45 \mathrm{~kg} \mathrm{~S}^{-1}$.

\section{Seed yield ( $\left.\mathrm{kg} \mathrm{ha}^{-1}\right)$}

Mean value of sulfur levels indicated that plots treated with $45 \mathrm{~kg} \mathrm{ha}^{-1}$ produced maximum (2701 kg ha-1) seed yield while minimum (1356 kg ha ${ }^{-1}$ ) seed yield was recorded in control plots. These results agree with those $[5,15]$ who reported that yield increased with the increase in $S$ level at $60 \mathrm{~kg} \mathrm{ha}^{-1}$ under the climatic condition of Faisal Abad. Rapeseed cultivars had also significant effect on grain yield. Sown Oscar cultivar attained $2340 \mathrm{~kg} \mathrm{ha}^{-1}$ seed yield while lowest seed yield of 1929 kg ha ${ }^{-1}$ Dunkled and Abasin-95 cultivars were statistically the same. These results are in agreement with [16] who reported that differences among the yield in these cultivars might be due to hereditary superiority, growth rate, crop yield potential, higher nutrient translocation, assimilation and dry matter partitioning. The interaction between $\mathrm{S} \times \mathrm{C}$ indicated by table 2 that all rapeseed cultivars produced maximum grain yield when increasing sulfur level up to $30 \mathrm{~kg} \mathrm{ha}^{-1}$. But a linear increase was occurred for grain yield when the cultivar Oscar was sown and treated with 45 $\mathrm{kg} \mathrm{S} \mathrm{ha}{ }^{-1}$.

\section{Oil yield ( $\left.\mathrm{kg} \mathrm{ha}^{-1}\right)$}

Mean value of sulfur levels indicated that plots treated with $45 \mathrm{~kg} \mathrm{ha}^{-1}$ produced maximum (1291 $\left.\mathrm{kg} \mathrm{ha}^{-1}\right)$ oil yield while the minimum $\left(642 \mathrm{~kg} \mathrm{ha}^{-1}\right)$ oil yield was recorded in control plots. These results agree with those $[5,17]$ they reported that yield increased with the increase in S level up to $60 \mathrm{~kg} \mathrm{ha}^{-1}$ under the climatic condition of Faisal Abad. Rapeseed cultivars had also significant effect on oil yield. Sown Oscar cultivar attained 1132 $\mathrm{kg} \mathrm{ha}^{-1}$ soil yield while lowest oil yield of $913 \mathrm{~kg} \mathrm{ha}^{-1}$ when the Dunkled cultivar sown it was not statistically difference than Abasin-95. These results are also in agreement with [18] who reported that differences among the yield in these cultivars might be due to hereditary superiority, growth rate, crop yield potential, higher nutrients translocation, assimilation and dry matter partitioning. Interaction between $\mathrm{S} \times \mathrm{C}$ indicated by table 2 that all rapeseed cultivars produced maximum oil yield when increasing sulfur level up to $30 \mathrm{~kg} \mathrm{ha}^{-1}$. But a linear increase was recorded for oil yield when the cultivar Oscar was sown and treated with $45 \mathrm{~kg} \mathrm{~S} \mathrm{ha}^{-1}$. Harvest index (\%)

Statistical analysis of harvest index data showed that sulfur and rapeseed cultivars had significant effect on harvest index while the interaction between $\mathrm{C} \times \mathrm{S}$ was not significant. Plots supplied with sulfur had significantly higher harvest index as compared to control plots. With the increase of sulfur level harvest index increasing significantly and therefore the highest level of sulfur (45 kg ha $\mathrm{ha}^{-1}$ produced the maximum harvest index (18\%) while lowest $(15 \%)$ harvest index was recorded in control plots. These results agree with the findings of [19] who reported that increasing rate of sulfur application significantly increased harvest index over control plots. Cultivar Oscar and Bulbul-98 recorded maximum $(17 \%)$ harvest index as compared to cultivar Abasin-95 produced (15\%) harvest index. It may be due to their genetic as well as phenotypic and hereditary superiority difference from other rapeseed cultivars.

\section{Conclusion}

From present research it can be concluded that cultivar Oscar treated with $45 \mathrm{~kg} \mathrm{~S} \mathrm{ha}^{-1}$ produced maximum capsules plant $^{-1}$, seeds 
capsule $^{-1}, 1000$ grain weight, grain and oil yield significantly and therefore, it is recommended that cultivar Oscar should be sown under the swat valley condition with the application of $\mathrm{S} 45 \mathrm{~kg} \mathrm{ha}^{-1}$ for higher yield and quality.

\section{References}

1. Ahmad G, Jan A, Ullah I \& Arif M (2006). Phenology and physiology as affected by nitrogen and sulfur fertilization. J. Agron 5(4):555-562.

2. Ahmad N, Saleem MT, Rashid M \& Jalil A (1994). Sulfur status and crop response in Pakistan soils. National fertilizer development center. Pub. No. 7/94. Planning and dev. Div., islamabad.1-5.

3. Begum, F, Hossain F \& Mondal M.R.I (2012). Influence of sulphur on morphophysiological and yield parameters of rapeseed (brassica campestris 1.) Issn 02587122 bangladesh. j. Agril. Res. 37(4): 645652.

4. Downey RK \& Remmer SR (1993). Agronomic improvement in oil seed Brasica Adv. Agron 45:1-66

5. Havlin JL, Beaton JD, Tisdale SL \& Nelson WL (2004). Soil fertility and fertilizers. An introduction to nutrient management.7th ed. Pearson Education Inc. Singapore. 221p.

6. Holmes MRJ (1980). Nutrition of the oil seed rape crop. Applied Sci Pub barkingessex, England. 21-67.

7. Jan MT, Shah P, Hollington PA, Khan MJ \& Sohail Q (2009). Agriculture Research: Design and Analysis, A monograph. Agric. Univ. Pesh. Pak.

8. Malik MA, Aziz I, Khan HZ \& Wahid MA (2004). Growth, seed yield and oil content response of canola (brassica napus 1.) To varying levels of sulphur. Int J Agric Bio 1560-8530/06-6-1153-1155.

9. MINFA (2011). Agriculture statistic of Pakistan, Ministry of food, agriculture and Livestock, Govt. of Pakistan, Islamabad.

10. Muhammad S, Khalil IA \& Khan S (1991). Fatty acid composition of rape and mustad oil seed cultivars. Sci. Khyber 4(1): 29-36.

11. NFDC (2005). Annual fertilizer review 2004-05. National fertilizer development centre. Planning and dev. Div. Islamabad. Nelson, d. W and 1. E. Sommers. 1982. Total carbon, organic carbon and organic matter. 574-577.

12. Rashid R., Karim MDF \& Mirza H (2007). Response of rapeseed (Brassica campestris L.) To different nitrogen doses and number of weeding middle-east. Journal of Scientific Research 2(3-4):146-145.

13. Sattar A, Cheema MA, Wahid MA, Saleem M.F \& Hassan M (2011). Interactive effect of sulphur and nitrogen on growth, yield and quality of Canola. Crop \& Environment 2(1): 32-37.

14. Sharifi RS (2012). Study of yield, yield attribute and dry matter accumulation of canola (brassica napus 1.) Cultivars in relation to sulfur fertilizer. Inter J Agric crop Sci 4 (7): 409-415.

15. Soleymani A, Shahri MM, Shahrajbian

MH \& Naranjani L (2010). Responses of cultivars of canola to sulfur fertilizer and plant densities under climatic condition of gorgan region, Iran. J food Agric Envi 8(3\&4): 298 - 304.

16. Imran (2015). Influence of Nitrogen Levels and Decapitation Stress on Biological

Potential of Rapeseed (Brassica Napus L) under Water Difficit Condition of SwatPakistan. J N Sci Res 5(3): 138-143.

17. Imran, Asad. AK, Inam.U \& Fayaz. A(2014). Production potential of rapeseed (brassica napus L.) As influenced by different nitrogen levels and decapitation stress under the rainfed agro-climatic condition of swat Pakistan. $J$ Glob Innov Agric 2(3): 112-115.

18. Imran \& Asad AK (2015). Biochar Application and Shoot Cutting Duration (Days) Influenced Growth, Yield and Yield Contributing Parameters of

Brassica Napus L. J. Bio, Agric and $H$. care 5(5): 1-7.

19.Imran \& Asad AK (2015). Phenological Charateristics of Brassica Napus L. as Influenced by Biochar Application and Shoot Cutting Duration (Days). Civi and Environ Res 7(3):104-107. 